\title{
Persistent organic pollutants in blood samples of Southern Giant Petrels (Macronectes giganteus) from the South Shetland Islands, Antarctica
}

Fernanda I. Colabuono ${ }^{\mathrm{a}}$, Stacy S. Vander Pol ${ }^{\mathrm{b}}$, Kevin M. Huncik ${ }^{\mathrm{b}}$, Satie Taniguchi ${ }^{\mathrm{a}}$, Maria V. Petry ${ }^{\mathrm{c}}$, John R. Kucklick ${ }^{\mathrm{b}}$, Rosalinda C. Montone ${ }^{\mathrm{a}}$

${ }^{a}$ Universidade de São Paulo, Instituto Oceanográfico, Laboratório de Química Orgânica Marinha, Praça do Oceanográfico 191, São Paulo, SP 05508-120, Brazil

${ }^{\mathrm{b}}$ National Institute of Standards and Technology, Hollings Marine Laboratory, 331 Fort Johnson Road, Charleston, SC 29412, USA

${ }^{c}$ Universidade do Vale do Rio dos Sinos, Laboratório de Ornitologia e Animais Marinhos 950, São Leopoldo, RS 93022-000, Brazil

Corresponding author: Fernanda I. Colabuono

Postal Adress: Universidade de São Paulo, Instituto Oceanográfico, Laboratório de Química Orgânica Marinha, Praça do Oceanográfico 191, São Paulo, SP 05508-120, Brazil

E-mail address: ficolabuono@gmail.com

Tel. +551130916570 


\section{Abstract}

Seabirds play an important role as top consumers in the food web and can be used as biomonitors of exposure to pollutants. Contamination studies involving nondestructive sampling methods are of considerable importance, allowing better evaluation of the levels of pollutants and their toxic effects. In the present study, organohalogen contaminants were analyzed in 113 blood samples from Southern Giant Petrel (Macronectes giganteus) adults and chicks collected in the austral summer of 2011/2012 and 2012/2013 from colonies on Elephant and Livingston Islands, South Shetland, Antarctica. Polychlorinated biphenyls (PCBs), hexachlorobenzene (HCB), pentachlorobenzene $(\mathrm{PeCB})$, mirex, dichlorodiphenyltrichloroetane and derivatives (DDTs) and chlordanes were detected in all birds, whereas polybrominated diphenyl ethers (PBDEs) were not detected in any blood samples. No significant differences were found in organochlorine levels between sampling events. Adults exhibited significantly higher levels than chicks, except for PeCB. PCBs, HCB, mirex and DDTs were statistically similar in males and females from Elephant Island. Females on Livingston Island exhibited higher HCB values than males, but no sex differences were found regarding other organochlorines. The similarity in organochlorine levels between sexes in birds with very marked sexual segregation in feeding habits during the breeding season may indicate that significant amounts of contaminants are acquired during migration to lower latitudes, when the diets of males and females are similar. Birds sampled on Livingston Island exhibited significantly lower levels of PCBs, HCB, DDTs, mirex and chlordanes in comparison to those on Elephant Island, which could be the result of distinct foraging patterns between the two colonies. Organochlorine levels were similar between years in birds captured in two consecutive breeding seasons. Blood samples from Southern Giant Petrels adults and chicks proved to be useful for the comparison of intraspecific contamination levels and appear to be adequate for the longterm assessment of organohalogen contaminants in antarctic top predators.

Organochlorine contaminants in blood samples of Southern Giant Petrels reflected intra-specific differences and suggested distinct foraging patterns between colonies.

Keywords: Procellariiformes; polychlorinated biphenyls; organochlorine pesticides; seabirds; Elephant Island; Livingston Island 


\section{Introduction}

Seabirds play an important role as top consumers in the food web and can be used as biomonitors of exposure to pollutants, revealing potential threats to the environment (Furness and Camphuysen, 1997). Several classes of contaminants, such as polychlorinated biphenyls (PCBs), polybrominated diphenyl ethers (PBDEs) and organochlorine pesticides (OCPs), are often found in the marine environment, including remote places, such as the Southern Ocean (e.g., Corsolini, 2009; Cipro et al., 2010). These contaminants are incorporated into the food web, reaching top predators due to bioaccumulation and biomagnification processes (Fisk et al., 2001).

Organic contaminants are usually analysed in lipid-rich tissues, such as the adipose tissue, liver and muscle, which usually limits sampling to dead specimens and constitutes an obstacle to ecotoxicological and long-term monitoring studies (Henriksen et al., 1998; Knudsen et al., 2007). Contamination studies using non-destructive sampling methods, such as the analysis of pollutants in the blood, can help overcome these limitations and are of considerable importance, allowing the evaluation of the levels of pollutants and their toxic effects (Bustnes et al., 2001), and has the advantage of repeated sampling from the same individual and a more representative sampling design (Furness and Camphuysen, 1997; Keller et al., 2004; Yordy et al., 2010; Carravieri et al., 2014). Additionally, blood contaminant concentrations were significantly correlated with concentrations in lipid-rich tissues in wildlife, such as marine mammals and seabirds, and in humans (Kanja et al., 1992; Boon et al., 1994; Henriksen et al., 1998).

The Southern Giant Petrel Macronectes giganteus (Procellariiformes: Procellariidae) is an important top predator of the South Atlantic and the Southern Ocean (Hunter, 1985; O’Brien, 1990) and breeds mainly on subantarctic islands, with colonies on the Antarctic continent and in Argentina (Marchant and Higgins, 1990; 
Carboneras, 1992). The largest populations of Southern Giant Petrel can be found on the Falkland, South Georgia and South Shetland Islands (Reid and Huin, 2008). Unlike the Falkland and South Georgia Islands, few studies, most of which have been related to ecology, have previously been conducted on this species in South Shetland Islands (e.g., Sander et al., 2010). During the non-breeding period, the Southern Giant Petrel migrates to lower latitudes in South America and Africa (Petry and Fonseca, 2002; Sander et al., 2010). Although this species is not classified as endangered by the International Union for Conservation of Nature (IUCN), the numbers of some populations have declined (18 to $50 \%$ ) in recent decades due to human activities (IUCN, 2014).

Characteristics, such as accentuated sexual dimorphism, segregated feeding habits between males and females (Hunter, 1983; González-Solís et al., 2002a; González-Solís and Croxall, 2005), a low reproduction rate, late maturity and extended longevity (Hunter, 1984; Voisin, 1988), make the Southern Giant Petrel a suitable species for the study of ecology, sexual trophic segregation and environmental contamination.

In the present study, we report levels of organohalogen contaminants, collectively referred to as persistent organic pollutants (POPs), in blood samples of Southern Giant Petrels from Livingston and Elephant Islands, South Shetland, Antarctica. Moreover, variations in POP levels were evaluated related to the sex and age of birds, as well as in individuals that were recaptured and sampled over two consecutive years. Results from this work provide help to put in context levels of persistent organic pollutants in Southern Ocean seabirds relative those from more studied locations such Northern Europe and the North American Arctic. 


\section{Material and Methods}

\subsection{Sample collection}

Blood samples $(n=113)$ of Southern Giant Petrels were collected in breeding colonies at Livingston Island $\left(62^{\circ} 36^{\prime} \mathrm{S}, 60^{\circ} 30^{\prime} \mathrm{W}\right)$ and Elephant Island $\left(61^{\circ} 13^{\prime} \mathrm{S}\right.$, $55^{\circ} 21^{\prime} \mathrm{W}$ ), South Shetland, Antarctica (Fig. 1). At Elephant Island, sampling of adults was conducted during two consecutive breeding seasons (November 2011 and November/December 2012), whereas chicks were sampled only in February 2013. At Livingston Island, blood samples were collected only in the December 2012, and only from adult birds. Approximately $4 \mathrm{~mL}$ of blood from the superficial ulnar artery were collected from each bird for contaminant analysis. The whole blood was stored in glass vials (previously baked at $\left.450{ }^{\circ} \mathrm{C}\right)$, containing heparin $(0.1 \mathrm{~mL}$ for each $1 \mathrm{~mL}$ of blood), and kept frozen at $-20{ }^{\circ} \mathrm{C}$ until analysis.

All captured birds were banded (the ring number was recorded for birds already banded in previous years) and the sex was identified by the morphology and morphometry (body weight, bill length, wing length and tarsal length) of the individual. Southern Giant Petrels show evident sexual dimorphism by size, with males being larger and heavier than females, and also with larger and more robust culmen (Hunter, 1984; Copello et al., 2006). All samples were collected with permits (Brazilian Antarctic Authorities and Environmental Ministry 2011 and 2012) in accordance to Annex II, Article 3 of the Protocol on Environmental Protection to the Antarctic Treaty and the regulation from the Scientific Committee on Antarctic Research (SCAR).

\subsection{Sample preparation}

Samples were analyzed for organic contaminants, according to the methods described by Keller et al. (2009), with minor modifications. Briefly, $3 \mathrm{~g}$ of sample was 
first amended with a suite of ${ }^{13} \mathrm{C}$ labeled internal standards in ethanol (mass known) and then allowed to equilibrate with the sample overnight at $4{ }^{\circ} \mathrm{C}$. Samples were then extracted twice in a focused microwave extractor (FME) (Discover, CEM Corp.) equipped with an autosampler (Explorer, CEM Corp.). Following extraction, acidified silica and alumina clean-ups were performed on automated SPE workstations (RapidTrace, Biotage). Samples were solvent-exchanged to iso-octane and reduced to a final volume of approximately $250 \mu \mathrm{L}$. The sample preparation method is described in detail in Supplementary Information (SI).

Aliquots of Standard Reference Material (SRM 1958 - Organic Contaminants in Fortified Human Serum, National Institutes of Standards and Technology - NIST) and in-house control material of pooled Southern Giant Petrels blood, as well as triplicate laboratory blanks and six calibration solutions for each batch were prepared using the same techniques. Calibration solutions were subjected to the same sample preparation steps, as were samples and laboratory blanks. Results from SRM 1958 were within the ranges of the certificate values (Table S1). All analyses were carried out at Hollings Marine Laboratory (National Institute of Standards and Technology [NIST] Chemical Sciences Division).

\subsection{Sample analysis}

Samples were analyzed on a gas chromatograph coupled to a triple quadrupole mass spectrometer (Agilent 7000 GC-MS/MS coupled to an Agilent 7890A gas chromatograph). A programmable temperature vaporization (PTV) inlet operated in the solvent vent mode was used for injections. Additional information about the chromatographic parameters is described in SI. 
Eighty-one PCB congeners and 12 OCPs were determined by GC-MS/MS in the electron ionization mode (EI) operated in multiple reaction monitoring (MRM). Compounds and transitions monitored are listed in Table S2. The guard column (5 m x $0.25 \mathrm{~mm}$ ) was connected to a DB-XLB capillary column (Agilent Technologies) with $30 \mathrm{~m} \times 0.18 \mathrm{~mm}, 0.18 \mu \mathrm{m}$ film thickness.

Twenty-five PBDE and five chlorinated pesticides were analyzed in the negative chemical ionization mode (NCI) operated in selected ion monitoring (SIM) (Table S3) using the same instrument but not in the MS/MS mode. The guard column (5 m x 0.25 $\mathrm{mm}$ ) was connected to a $5 \%$ phenyl methylpolysiloxane capillary column (DB-5MS, Agilent Technologies) with $30 \mathrm{~m} \times 0.18 \mathrm{~mm}, 0.18 \mu \mathrm{m}$ film thickness.

Amounts of each analyte were calculated using the slope and y-intercept of at least a three-point calibration curve. A compound was considered to be significantly above the limit of detection (LOD) if the mass of an analyte in the sample was greater than the mass of the analyte in the lowest detectable calibrant solution and also above the average mass of the analyte detected in blanks + three times the standard deviation of the blank response. Average LOD values for all analytes are showed in Table S4.

Lipid analyses were carried out using the SmartTrac II from CEM (Matthews, NC). An aliquot (approximately $250 \mu \mathrm{L}$ ) of the sample was dried in a microwave and total fat was determined by nuclear magnetic resonance (NMR). Each blood sample was analyzed in triplicate in the NMR. Replicates of the SRM 1958 were analysed with each set of 18 samples.

\subsection{Statistics}

Normality and equality of variance assumptions were checked before analysis using Shapiro Wilk and Levene's test, respectively. Data did not meet these 
assumptions, even after log transformation, thus Kruskal-Wallis test followed by pairwise Wilcoxon rank sum tests, using Bonferroni adjustment to the alpha value, were used to confirm differences in organic contaminants levels between years, locations, ages and sexes. All statistical analyses were performed using the software program $\mathrm{R}$ 3.0.2 (R Development Core Team 2013) with a significance level of $5 \%$.

\section{Results and Discussion}

Organohalogen contaminants were detected in the blood samples of all Southern Giant Petrels adults and chicks (Table 1, Tables S5-S7). Mirex (2.56 to $43.1 \mathrm{ng} \mathrm{g}^{-1}$ ) and DDTs (2.16 to $34.5 \mathrm{ng} \mathrm{g}^{-1}$ ) were the predominant compounds detected in adults, followed by PCBs (2.14 to $21.55 \mathrm{ng} \mathrm{g}^{-1}$ ) and $\mathrm{HCB}$ (1.85 to $12.1 \mathrm{ng} \mathrm{g}^{-1}$ ). Chicks exhibited a different pattern [DDTs $\left(0.61\right.$ to $\left.5.00 \mathrm{ng} \mathrm{g}^{-1}\right)>\mathrm{HCB}\left(0.98\right.$ to $\left.3.61 \mathrm{ng} \mathrm{g}^{-1}\right)>$ mirex $\left(0.28\right.$ to $\left.2.63 \mathrm{ng} \mathrm{g}^{-1}\right)>\operatorname{PCBs}\left(0.09\right.$ to $\left.1.65 \mathrm{ng} \mathrm{g}^{-1}\right)$, which may be related to differences in exposure to these contaminants (Fig. S1).

Chicks reflect exposure from maternal transfer to the egg and food provided by parents during the rearing period (Verreault et al., 2006; Foster et al., 2010), whereas adults reflect contamination from their breeding grounds and migration areas (Tanaka et al., 1986). HCB, 4,4'-DDE and PCBs are the predominant contaminants found in antarctic organisms, such as seals, penguins, fish and krill (Corsolini et al., 2007; Corsolini, 2009; Cipro et al., 2010), which are important prey for Southern Giant Petrels during the breeding season (Forero et al., 2005; Rey et al., 2012).

Mirex, which was one of the most abundant contaminant found in the blood of Southern Giant Petrel adults, has been found at higher levels in birds that migrate to lower latitudes of the Southern Hemisphere (e.g., Brown Skuas), than in resident birds (e.g., penguins) (Taniguchi et al., 2009; Cipro et al., 2013), which indicates that 
exposure to this compound mainly occurs in regions other than Antarctica. Mirex was used in the northern and southern hemispheres to combat ants and termites and as a flame retardant (Ritter et al., 1995). Although it has not been used in the United States since 1978 (IARC, 1979; ATSDR, 1995), mirex had continuous use in South America and Australia until the late 2000s (Barra et al., 2006; DEH, 2006). The abundance of mirex in blood samples of Southern Giant Petrels reflects the use of this substance in the southern hemisphere.

Table 2 shows organic contaminant levels in the blood of Southern Giant Petrels and of high trophic level seabirds from North Atlantic, Arctic, Antarctic and Subantarctic regions, reported in previous studies. Southern Giant Petrels had overall organic contaminant levels lower than birds from Northern Hemisphere. PCB, DDT and chlordane levels in Southern Giant Petrels were up to two orders of magnitude lower than those reported in Glaucous Gulls (Larus hyperboreus) and Great Skuas (Catharacta skua). Glaucous Gulls and Great Skuas breed in high latitudes of the Northern Hemisphere, and like Southern Giant Petrel, they have migratory habits and occupy a high trophic position in the food web (del Hoyo et al., 1996). Differences in HCB and mirex levels among these species were less pronounced. Southern Giant Petrels presented HCB and mirex values in the same magnitude range of Glaucos Gulls and of Great Skuas from Iceland and Shetland (Sonne et al., 2013; Bustnes et al., 2006).

Organochlorine levels in South Polar Skuas (Catharacta maccormicki), from East Antarctica (Bustnes et al., 2006), were higher (but in the same magnitude order) than those found in adults of Southern Giant Petrels. Southern Giant Petrels had organochlorine levels comparable to those reported in Wandering Albatrosses (Diomedea exulans), a circumpolar migrant from the Southern Hemisphere, except for 
PCBs, which presented maximum values higher in Wandering Albatrosses (Carravieri et al., 2014).

PCBs have been frequently reported as one of the predominant contaminants in the antarctic biota (e.g., Cipro et al., 2013; Corsolini, 2009). The hexa- and heptacongeners of PCBs were predominant in all birds (Table 1), representing $30.5 \%$ to $65.7 \%$ and 21.9 to $58.3 \%$ of total PCBs for each homolog group, respectively. The most representative congeners within these groups were PCBs 138, 153+132, 170 and 180 (Fig. S2). The prevalence of high-chlorinated PCBs is due to the accumulation of these compounds and the excretion of lower chlorinated congeners by higher trophic level organisms (Maervoet et al., 2004).

Pentachlorobenzene $(\mathrm{PeCB})$ was used as a mixture in $\mathrm{PCB}$ products, as a fungicide, a flame retardant and is also a byproduct of a variety of industrial process (Bailey et al., 2009). In the present study, PeCB was detected in all individuals, with levels ranging from $0.06 \mathrm{ng} \mathrm{g}^{-1}$ to $0.43 \mathrm{ng} \mathrm{g}^{-1}$ (Table 1). PeCB is a persistent organic pollutant and has been found in the arctic marine food web (Nostrom et al., 1988) as well as recently reported in fishes, penguins and other birds from Antarctica (Goutte et al., 2013).

The chlordane group was represented in the blood samples of Southern Giant Petrels mainly by oxychlordane, although trans-nonachlor was also detected in blood samples. Oxychlordane, which is a metabolite of cis-and trans-chlordane and nonachlor (Eisler, 1990), is persistent and continues to be frequently detected in wildlife in remote locations (e.g., Henricksen et al., 2000; Bustnes et al., 2001). Birds can metabolize chlordanes to oxychlordane more efficiently than other organisms, usually showing higher proportion of this compound in their tissues (Kawano et al., 1988). Cis-chlordane 
$\left(\mathrm{LOD}<0.02 \mathrm{ng} \mathrm{g}^{-1}\right)$, trans-chlordane $\left(\mathrm{LOD}<0.005 \mathrm{ng} \mathrm{g}^{-1}\right.$ ) and cis-nonachlor $(\mathrm{LOD}<$ $0.005 \mathrm{ng} \mathrm{g}^{-1}$ ) were not detected in blood samples.

PBDEs (LOD $<0.003 \mathrm{ng} \mathrm{g}^{-1}$ ) and HCHs (LOD $<0.01 \mathrm{ng} \mathrm{g}^{-1}$ ) were not detected in the blood samples of Southern Giant Petrels. PBDEs have been found in eggs, internal tissues and the plasma of antarctic and subantarctic birds, but usually at low levels (Carravieri et al., 2014; Bustness et al., 2006; Corsolini et al., 2006). In Antarctica, HCHs are mainly detected in organisms on low trophic levels and birds that feed mainly on krill (Corsolini et al., 2006; Corsolini et al., 2011; Taniguchi et al., 2009). Moreover, HCHs are rapidly metabolized and excreted by birds, and consequently are less prone to accumulate in their tissues (Clark et al., 1987).

\subsection{Intra-specific comparisons on organic contaminant levels}

Levels of PCBs and OCPs were similar between breeding seasons for males and females on Elephant Island ( $p$ > 0.05) (See SI, Table S8 for Wilcoxon comparisons and p-values). Thus, samples from different years were pooled for subsequent analyses.

Differences in contaminant levels are usually expected in species with sexual trophic segregation (Gonzáles-Solís et al., 2002b; Carravieri et al., 2014), such as Southern Giant Petrels. Southern Giant Petrel males and females exhibited a high degree of similarity in contaminant levels (Table 1; Fig. 2). Statistically significant ( $<$ 0.05) differences between sexes were found only for PeCB and chlordanes in birds on Elephant Island (higher levels in males), and only for HCB ( $\mathrm{p}<0.05)$ in birds on Livingston Island (higher levels in females) (Fig. 2; Table S8).

During the breeding season, males feed mainly on carrion, such as penguins and seals, while females rely greater on marine prey, such as fish and cephalopods (Hunter, 1983; Forero et al., 2005; Rey et al., 2012). However, during the migration season, the 
diet of Southern Giant Petrel males and females appears to be similar, with greater dependence on marine resources than carrion for both sexes (Hunter, 1983; Bugoni et al., 2010). Thus, one may infer that that males and females have similar contamination levels due to the more significant uptake of contaminants at lower latitudes during the migration period, when their feeding habits are more alike.

An additional aspect to consider is that the contamination found in components in the blood is the result of 1) the recent intake through food, 2) the mobilization of compounds from lipid-rich tissues and 3) the redistribution of contaminants to blood and internal tissues (Henriksen et al., 1998; van den Brink et al., 1998; Bustnes et al., 2010). Thus, the blood samples of Southern Giant Petrels likely reflect contamination over a general period and not only recent exposure after the birds have arrived at breeding colonies.

Levels of organochlorine contaminants in chicks were clearly lower than adults (Table 1; Fig. 2). Significant differences between ages were found for PCBs, PeCB, HCB, DDTs, mirex and chlordanes $(\mathrm{p}<0.05)$ (Table S8). In addition to the contamination acquired during the embryonic period, chicks are constantly exposed to these contaminants during the rearing period. Petrels feed their young with stomach oils produced from their diet, which has a high lipid content and concentrated levels of organochlorines derived from preys (Warham, 1977; Foster et al., 2010). However, chicks accumulate these compounds for a short period of time (two or three months), which partial explains the low levels in their blood in comparison to breeding adults, which are at least five to six years of age (average age at first breeding) (Marchants and Higgins, 1990). Growth dilution may be also a significant factor leading to lower organochlorine levels in chicks than in their parents (Bourgeon et al., 2013). 


\subsection{Differences between colonies - Elephant Island vs. Livingston Island}

Birds on Livingston Island exhibited, in general, lower contaminant levels than those on Elephant Island, with more noticeable differences for males than females (Fig. 2). Males on Livingston Island exhibited significantly lower $(\mathrm{p}<0.05)$ levels than males on Elephant Island for five classes of chlorinated contaminants (HCB, DDTs, mirex, PCBs and chlordanes) $(\mathrm{p}<0.05)$ (Table S8). Significant differences were also found between the two islands for females on, where HCB and mirex levels were significantly $(\mathrm{p}<0.05)$, lower on Livingston Island than on Elephant Island (Table S8).

Geographic differences in contamination levels may be caused by segregation in foraging areas among Southern Giant Petrel colonies, despite the proximity between the two breeding sites. Elephant Island is situated in the northernmost portion of the South Shetland Islands and is about 300 kilometers from Livingston Island (Fig. 1). During the migration and/or breeding season, males on Elephant Island may forage mainly at lower latitudes and therefore in more contaminated areas than males on Livingston Island, which likely spend more time foraging at higher latitudes of the Southern Ocean.

Differences in foraging strategies between females of the two colonies may be less striking than males, which are reflected in contamination levels. Different foraging patterns among Southern Giant Petrel colonies and between sexes have been reported for other locations, such as South Georgia and Patagonia (Gonzáles-Solís et al., 2000; Forero et al., 2005; Quintana et al., 2010; Petry and Kruger, 2011; Rey et al., 2012). During the breeding period, males forage closer to the colony, and therefore, provisioning chicks more frequently than females (Hunter, 1983; Gonzáles-Solís et al., 2000). However, there is a lack of information regarding Southern Giant Petrel foraging strategies, mainly during their non-breeding season, on Elephant and Livingston Islands 
and assumptions regarding differences in foraging patterns in these areas need to be investigated further.

\subsection{Recaptures}

Despite the small number of individuals recaptured, it was possible to notice that organohalogen concentrations in blood samples of all five birds were very similar between the two sampling years (Table 3), with no statistical differences ( $p>0.05)$ (Table S8).

Several factors can influence the toxicokinetics of organochlorines in organisms, such as variations in diet, food resources and body condition. For example, Bustnes et al. (2001) found no significant changes in organochlorine levels among breeding seasons for Glaucous Gulls, which were in a relatively stable environment in terms of food sources (Bustnes et al., 2000). On the other hand, Great Black-backed Gulls (Larus marinus), which usually experience a considerable variation in food availability, exhibited high intra-individual variability between two consecutive breeding seasons (Bustnes et al., 2005). The effect of environmental conditions on individual contaminant levels may lead to incorrect conclusions regarding trends in contaminant levels in the environment (Bustnes et al., 2005). Thus, bird species with low short-term variability in organochlorine levels, such as that observed in the present study on the Southern Giant Petrel, may be more effective monitors in long-term assessments.

Organic contaminant levels in birds are generally monitored using eggs, liver, and blood samples from different individuals (e.g., Elliott and Shutt, 1993; Braune et al., 2007, Vander Pol and Becker, 2007). However, seabirds usually present high degree of intraspecific variability regarding levels of PCBs and OCPs (Elliott, 2005; 
Colabuono et al., 2012), which may be attributed to several factors, such as diet, age and distribution (Elliott, 2005). Thus, repeated sampling from the same individuals provides a more accurate evaluation of temporal trends in environmental contamination in a long-term monitoring.

\section{Conclusions}

The results presented herein contribute to information on organohalogen contaminants in antarctic top predators. Blood samples from Southern Giant Petrels adults and chicks have proven useful to compare contamination levels in these birds. Mirex, DDTs, PCBs and HCB were the predominant compounds in blood samples. Organic contaminant levels were higher in adults than chicks as a consequence of bioaccumulation during breeding and wintering periods. In general, no sex differences in organochlorine levels were found, but geographic differences between colonies were detected in contamination levels, suggesting different foraging patterns by birds from Elephant and Livingston Islands. Differences in diet and foraging areas of Southern Giant Petrels in both colonies should be better investigated using stable isotopes and/or geolocators. Despite the small number of recovered birds, organohalogen levels in blood samples from breeding adults generally appeared not to change after one year. Greater efforts to recapture ringed birds would be useful for long-term monitoring to assess trends in organohalogen levels in the antarctic environment.

\section{Acknowledgments}

This study is part of the National Science and Technology Institute on Antarctic Environmental Research (INCT-APA - CNPq 574018/2008-5 and FAPERJ E16/170023/2008) funded by the Brazilian Antarctic Program (PROANTAR). Logistical 
support was provided by the Brazilian Secretary of the Inter-Ministry on Marine Resources (SECIRM). The authors are thankful to the Hollings Marine Laboratory (National Institute of Standards and Technology [NIST] Chemical Sciences Division) where the organic contaminant analyses of the blood samples of Southern Giant Petrels were performed. We also thank the team of Laboratory of Ornithology and Marine Animals (Universidade do Vale do Rio dos Sinos). F.I. Colabuono received a research grant from the São Paulo Research Foundation (Fapesp).

\section{Disclaimer}

Any mention of commercial products is for information only; it does not imply recommendation or endorsement by NIST.

\section{References}

ATSDR. Toxicological profile for mirex and chlordone. Agency for Toxic Substances and Disease Registry 1995. http://www.atsdr.cdc.gov/toxprofiles/tp66.pdf

Bailey RE, Wijk D, Thomas PC. Sources and prevalence of pentachlorobenzene in the environment. Chemosphere 2009; 75: 555-564.

Barra R, Colombo JC, Eguren G, Gamboa N, Jardim WF, Mendonza G. Persistent organic pollutants (POPs) in Eastern and Western South American countries. In: Ware GW, editor. Reviews of Environmental Contamination and Toxicology Volume 185. New York: Springer; 2006. p. 1-34.

Boon JP, Oostingh I, van der Meer J, Hillebrand MTJ. A model for the interpretation of chlorinated biphenyl concentrations in marine mammals. European Jornal of Pharmacology 1994; 270: 237-251 
Bourgeon S, Leat EKH, Furness RW, Borgå K, Hanssen SA, Bustnes JO. Dietary versus Maternal Sources of Organochlorines in Top Predator Seabird Chicks: An Experimental Approach. Environmental Science \& Technology 2013; 47(11): 5963-5970.

Braune BM. Temporal trends of organochlorines and mercury in seabird eggs from the Canadian Arctic, 1975-2003. Environmental Pollution 2007; 148: 599-613.

Bugoni L, Mcgill RAR, Furness RW. The importance of pelagic longline fishery discards for a seabird community determined through stable isotope analysis. Journal of Experimental Marine Biology and Ecology 2010; 391: 190-200.

Bustnes JO, Erikstad KE, Bakken V, Mehlum F, Skaare JU. Feeding ecology and the concentration of organochlorines in glaucous gulls. Ecotoxicology 2000; 9: 179186.

Bustnes JO, Skaare JU, Erikstad KE, Bakken V, Fritjof M. Whole blood concentrations of organochlorines as a dose metric for studies of the glaucous gull (Larus hyperboreus). Environmental Toxicology and Chemistry 2001; 20: 1046-1052.

Bustnes JO, Skaare JU, Berg V, Tveraa T. Interseasonal variation in blood concentrations of organochlorines in great black-backed gulls (Larus marinus). Environmental Toxicology and Chemistry 2005; 7: 1801-1806.

Bustnes JO, Tveraa T, Henden JA, Varpe $\varnothing$, Skaare JU. Organochlorines in Antarctic and Arctic avian top predators: a comparison between the south polar skua and two species of northern hemisphere gulls. Environmental Science and Technology 2006; 40: 2826-2831.

Bustnes JO, Moe B, Herze D, Sveinn AH, Nordstad T, Sagerup K, Gabrielsen G., Borgå K. Strongly increasing blood concentrations of lipid-soluble organochlorines in 
high Arctic common eiders during incubation fast. Chemosphere 2010; 79: 320325.

Carboneras C. Order Procellariiformes. In: del Hoyo J, Elliot A, Sargatal J, editors. Handbook of the birds of the world Vol. 1. Barcelona: Lynx Edicions; 1992. p. 98278.

Carravieri A, Bustamante P, Tartu S, Meillère A, Labadie P, Budzinski H, Peluhet L, Barbraud C, Weimerskirch $\mathrm{H}$, Chastel O, Cherel Y. Wandering albatrosses document latitudinal variations in the transfer of persistent organic pollutants and mercury to Southern Ocean predators. Environmental Science and Technology 2014; 48: 14746-14755.

Cipro CVZ, Taniguchi S, Montone RC. Occurrence of organochlorine compounds in Euphausia superba and unhatched eggs of Pygoscelis genus penguins from Admiralty Bay (King George Island, Antarctica) and estimation of biomagnification factors. Chemosphere 2010; 78: 767-771.

Cipro CVZ, Colabuono FI, Taniguchi S, Montone RC. Persistent organic pollutants in bird, fish and invertebrate samples from King George Island, Antarctica. Antarctic Science $2013 ; 25:$ 545-552.

Clark TP, Norstrom RS, Fox GA, Won HT. Dynamics of organochlorine compounds in herring gulls (Larus argentatus): II. A two-compartment model and data for ten compounds. Environmental Toxicology and Chemistry 1987; 6: 547-559.

Colabuono FI, Taniguchi S, Montone RC. Organochlorine contaminants in albatrosses and petrels during migration in South Atlantic Ocean. Chemosphere 2012; 86: 701708. 
Copello S, Quintana F, Somoza G. Sex determination and sexual size-dimorphism in Southern Giant-Petrels (Macronectes giganteus) from Patagonia, Argentina. Emu 2006; 106: 141-146.

Corsolini S, Covaci A, Ademollo N, Focardi S, Schepens P. Occurrence of organochlorine pesticides (OCPs) and their enantiomeric signatures, and concentrations of polybrominated diphenyl ethers (PBDEs) in the Adélie penguin food web, Antarctica. Environmental Pollution 2006; 140: 371-382.

Corsolini S, Borghesi N, Schiamone A, Focardi S. Polybrominated diphenyl ethers, polychlorinated dibenzo-dioxins, -furans, and -byphenyls in three species of Antarctic penguins. Environmental Science and Pollution Research 2007; 14: 421429.

Corsolini S. Industrial contaminants in Antarctic biota. Journal of Chromatography A 2009; 1216: 598-612.

Corsolini S, Borghesi N, Ademollo N, Focardi S. Chlorinated biphenyls and pesticides in migrating and resident seabirds from East and West Antarctica. Environment International 2011; 37: 1329-1335.

DEH. Stockholm Convention of Persistent Organic Pollutants: Australia's National Implementation Plan. Department of the Environment and Heritage 2006. http://www.environment.gov.au/system/files/pages/8b9d215a-de3a-4bfd-805365db6c9675c5/files/stockholm-nip.pdf

del Hoyo J, Elliott A, Sargatal J. Handbook of the birds of the world Vol. 3: Hoatzin to Auks. 1996. Barcelona: Lynx Edicions.

Eisler R. Chlordane hazards to fish, wildlife, and invertebrates: A synoptic review. Washington: U.S. Fish and Wildlife Service; 1990. 
Elliott JE, Shutt L. Monitoring of organochlorines in blood of sharp-shinned hawks (Accipiter striatus) migrating through the Great Lakes. Environmental Toxicology and Chemistry 1993; 12: 241-250.

Elliott JE. Chlorinated hydrocarbon contaminants and stable isotope ratios in pelagic seabirds from the North Pacific Ocean. Archives of Environmental Contamination and Toxicology 2005; 49: 89-96.

Fisk AT, Hobson KA, Norstrom RJ. Influence of chemical and biological factors on trophic transfer of persistent organic pollutants in the northwater Polynya marine food web. Environmental Science and Technology 2001; 35: 732-738.

Forero MG, González-Solís J, Hobson KA, Donázar JA, Bertellotti M, Blanco G, Bortolotti GR. Stable isotopes reveal trophic segregation by sex and age in the Southern giant petrel in two different food webs. Marine Ecology Progress Series 2005; 296: 107-113.

Foster KL, Wang SW, Mackay D, Mallory ML, Blais JM. Preliminary assessment of avian stomach oils: a vector of contaminants to chicks and potential for diet analysis and biomonitoring. Environmental Science and Technology 2010; 44: 6869-6874.

Furness RW, Camphuysen, CJ. Seabirds as monitors of the marine environment. ICES Journal of Marine Science 1997; 54: 726-737.

González-Solís J, Croxall JP, Wood AG. Foraging partitioning between giant petrels Macronectes spp. and its relationship with breeding population changes at Bird Island, South Georgia. Marine Ecology Progress Series 2000; 204: 279-288.

González-Solís J, Croxall JP, Briggs DR. Activity patterns of giant petrels Macronectes spp. using different foraging strategies. Marine Biology 2002a; 140: 197-204. 
González-Solís J, Sampera C, Ruiz X. Metals and selenium as bioindicators of geographic and trophic segregation in Giant petrels Macronectes spp. Marine Ecology Progress Series 2002b; 244: 257-264.

González-Solís J, Croxall JP. Differences in foraging behaviour and feeding ecology in giant petrels. In: Ruckstuhl KE, Neuhaus $\mathrm{P}$ editors. Sexual segregation in vertebrates: ecology of the two sexes. Cambridge: Cambridge University Press; 2005. p. 92-111.

Goutte A, Chevreuil M, Alliot F, Chastel O, Cherel Y, Eléaume M, Massé G. Persistent organic pollutants in benthic and pelagic organisms off Adélie Land, Antarctica. Marine Pollution Bulletin 2013; 77: 82-89.

Henriksen EO, Gabrielsen GW, Skaare JU. Validation of the use of blood samples to assess tissue concentrations of organochlorines in glaucous gull (Larus hyperboreus). Chemosphere 1998; 37: 2627-2643.

Henriksen EO, Gabrielsen GW, Trudeau S, Wolkers H, Sagerup K, Skaare JU. Organochlorines and possible biochemical effects in glaucous gulls (Larus hyperboreus) from Bjùrnùya, the Barents Sea. Archives of Environmental Contamination and Toxicology 2000; 38: 234-243.

Hunter S. The food and feeding ecology of the giant petrels Macronectes halli and $M$. giganteus at South Georgia. Journal of Zoology 1983; 200: 521-538.

Hunter, S. Breeding biology and population dynamics of giant petrels Macronectes at South Georgia (Aves: Procellariiformes). Journal of Zoology 1984; 203: 441-460.

Hunter S. The role of giant petrels in the Southern Ocean ecosystem. In: Siegfried WR, Condy PR, editors. Antarctic nutrient cycles and food webs. Berlin: SpringerVerlag; 1985. p. 534-542. 
IARC. Mirex. IARC monographs on the evaluation of the carcinogenic risk of chemicals to humans. Some halogenated hydrocarbons, volume 20. Lyon: IARC; 1979. p. 283-301.

International Union for Conservation of Nature (IUCN). Red list of threatened species. 2014. www.iucnredlist.org.

Kanja LW, Skaare JU, Ojwang SBO, Maitai CK. A comparison of organochlorine pesticide residues in maternal adipose tissue, maternal blood, cord blood, and human milk form mother/infant pairs. Archives of Environmental Contamination and Toxicology 1992; 22: 21-24.

Kawano M, Inoue T, Wada T, Hidaka H, Tatsukawa, R. Bioconcentration and residue patterns of chlordane compounds in invertebrates, fish, mammals, and seabirds. Environmental Science and Technology 1988; 22: 792-797.

Keller JM, Kucklick JR, Mcclellan-Green PD. Organochlorine contaminants in loggerhead sea turtle blood: extraction techniques and distribution among plasma and red blood cells. Archives of Environmental Contamination and Toxicology 2004; 46: 254-264.

Keller JM, Swarthout RF, Carlson BKR, Yordy J, Guichard A, Schantz MM, Kucklick. Comparison of five extraction methods for measuring PCBs, PBDEs, organochlorine pesticides, and lipid content in serum. Analytical and Bioanalytical Chemistry 2009; 393: 747-760.

Knudsen LB, Borgå K, Jørgensen EH, van Bavel B, Schlabach M, Verreault J, Gabrielsen GW. Halogenated organic contaminants and mercury in northern fulmars (Fulmarus glacialis): levels, relationships to dietary descriptors and blood to liver comparison. Environmental Pollution 2007; 146: 25-33. 
Maervoet J, Chu SG, Vos SD, Covaci A, Voorspoels S, Schrijver RD, Schepens P. Accumulation and tissue distribution of selected polychlorinated biphenyl congeners in chickens. Chemosphere 2004; 57: 61-66.

Marchant S, Higgins PJ. Handbook of Australian, New Zealand, and Antarctic birds, Vol. 1. Melbourne: Oxford University Press; 1990.

Norstrom RJ, Simon M, Muir DCG, Schweinsburg RE. Organochlorine contaminants in Arctic marine food chains: Identification, geographical distribution, and temporal trends in polar bears. Environmental Science and Technology 1988; 22: 1063-1071.

O’Brien RM. Southern giant petrel Macronectes giganteus. In: Marchant S, Higgins PJ editors. Handbook of the Australian, New Zealand \& Antarctic birds. Melbourne: Oxford University Press; 1990. p. 356-369.

Petry MV, Fonseca VSS. Effects of human activities in the marine environment on seabirds along the coast of Rio Grande do Sul, Brazil. Ornitologia Neotropical 2002; 13: 137-142.

Petry MV, Kruger L. Foraging distribution of an Antarctic Southern Giant Petrel population. Annual activity report of National Institute of Science and Technology Antarctic environmental research 2011, 88-91.

Quintana F, Dell' Arciprete P, Copello S. Foraging behaviour and habitat use by the Southern Giant Petrel on the Patagonian Shelf. Marine Biology 2010; 157: 515525.

Reid T, Huin N. Census of the Southern Giant Petrel population of the Falkland Islands 2004/2005. Bird Conservation International 2008; 18: 118-128.

Rey AR, Polito M, Archuby D, Coria N. Stable isotopes identify age- and sex-specific dietary partitioning and foraging habitat segregation in Southern giant petrels 
breeding in Antarctica and southern Patagonia. Marine Biology 2012; 159: 13171326.

R Development Core Team (2013). R: A language and environment for statistical computing. R Foundation for Statistical Computing, Vienna, Austria. ISBN 3900051-07-0, URL http://www.R-project.org.

Ritter L, Solomon KR, Forget J, Stemeroff M, O'Leary C. Persistent Organic Pollutants: An Assessment Report on: DDT, Aldrin, Dieldrin, Endrin, Chlordane, Heptachlor, Hexachlorobenzene, Mirex, Toxaphene, Polychlorinated Biphenyls, Dioxins and Furans. International Programme on Chemical Safety (IPCS) 1995. http://www.chem.unep.ch/POPS/ritter/en/ritteren.pdf

Sander M, Garcia SA, Carneiro APB, Cristofoli SI, Polito MJ. Band recoveries and juvenile dispersal of Southern Giant Petrels Macronectes giganteus marked as chicks in Antarctica by the Brazilian Antarctic Program (1984-1993). Marine Ornithology 2010; 38: 119-124.

Sonne C, Rigét FF, Leat EH, Bourgeon S, Borgå K, Strøm H, Hanssen SA, Gabrielsen GW, Petersen A, Olafsdottir K, Magnusdottir E, Bustnes JO, Furness RW, Kjelgaard-Hansen M. Organohalogen contaminants and blood plasma clinicalchemical parameters in three colonies of North Atlantic Great skua (Stercorarius skua). Ecotoxicology and Environmental Safety 2013; 92: 245-251.

Tanaka H, Ogi H, Tanabe S, Tatsukawa R, Oka N. Bioaccumulation and metabolism of PCBs and DDE in short-tailed shearwater Puffinus tenuirostris during its transequatorial migration and in the wintering and breeding grounds. Memoirs of National Institute of Polar Research 1986; 40: 434-442.

Taniguchi S, Montone RC, Bícego MC, Colabuono FI, Weber RR, Sericano JL. Chlorinated pesticides, polychlorinated biphenyls and polycyclic aromatic 
hydrocarbons in the fat tissue of seabirds from King George Island, Antarctica. Marine Pollution Bulletin 2009; 58: 129-133.

van den Brink NW, Van Franeker JA, Ruiter-Dijkman EM. Fluctuating concentrations of organochlorine pollutants during a breeding season in two Antarctic seabirds: adélie penguin and southern fulmar. Environmental Toxicology and Chemistry 1998; 4: 702-709.

Vander Pol, SS, Becker PR. Monitoring contaminants in seabirds: The importance of specimen banking. Marine Ornithology 2007; 35: 113-118

Verreault J, Villa RA, Gabrielsen GW, Skaare JU, Letcher RJ. Maternal transfer of organohalogen contaminants and metabolites to eggs of Arctic-breeding glaucous gulls. Environmental Pollution 2006; 144: 1053-1060.

Voisin JF. Breeding biology of the Northern giant petrel Macronectes halli and the Southern giant petrel M. giganteus at Ile de la Possession, Iles Crozet 1966-1980. Cormorant 1988; 16: 65-97.

Warham, J. The incidence, functions and ecological significance of petrel stomach oils. Proceedings of New Zealand Ecological Society 1977; 24: 84-93.

Yordy JE, Wells RS, Balmer BC, Schwacke LH, Rowles TK, Kucklick JR. Partitioning of persistent organic pollutants between blubber and blood of wild bottlenose dolphins: implications for biomonitoring and health. Environmental Science and Technology 2010; 44: 4789-95. 


\section{Captions}

\section{Tables}

Table 1. Median and range levels of organic contaminants (ng $\mathrm{g}^{-1}$ wet weight) analyzed in blood samples of Southern Giant Petrels (Macronectes giganteus). $\Sigma$ PCBs $=$ sum of 81 congeners $; \Sigma$ PBDEs $=$ sum of 25 congeners.

Table 2. Levels ${ }^{(1)}$ of organic contaminants (ng g ${ }^{-1}$ wet weight) found in blood samples of Southern Giant Petrels adults and of high trophic level seabirds species from the Southern and Northern Hemispheres.

Table 3. Organochlorine contaminant levels (ng $\mathrm{g}^{-1}$ wet weight) in blood samples of five recaptured birds from Elephant Islands. Birds were first sampled in November 2011, with second sampling in November 2012. $\Sigma$ PCBs $=$ sum of 81 congeners; $\Sigma$ DDTs $=$ sum of 2,4'-DDE, 4,4'-DDE, 2,4'-DDD, 2,4'-DDT, 4,4'-DDD, 4,4'-DDT; $\Sigma$ Chlordanes $=$ sum of trans-chlordane, cis-chlordane, trans-nonachlor, cis-nonachlor and oxychlordane.

\section{Figures}

Figure 1. Study area in South Shetland Islands, Antarctica. Southern Giant Petrel colonies where sampling was conducted are situated on Stinker Point (Elephant Island) and Hannah Point (Livingston Island). Map modified from SCAR Antarctic Digital Database. 
Figure 2. Organic contaminant levels (median in ng g-1 wet weight) in blood of Southern Giant Petrels from Elephant and Livingston Islands. Data from two breeding seasons were pooled. Comparisons within islands: equal letters above bars indicate no statistically significant differences between ages and between sexes within each island. Comparisons between islands: One asterisk $(*)$ indicates no statistically significant differences between females from Elephant and Livingston Islands, and two asterisks (**) indicates no statistically significant differences between males from the two different islands. The statistical significance level used was 0.05 . 


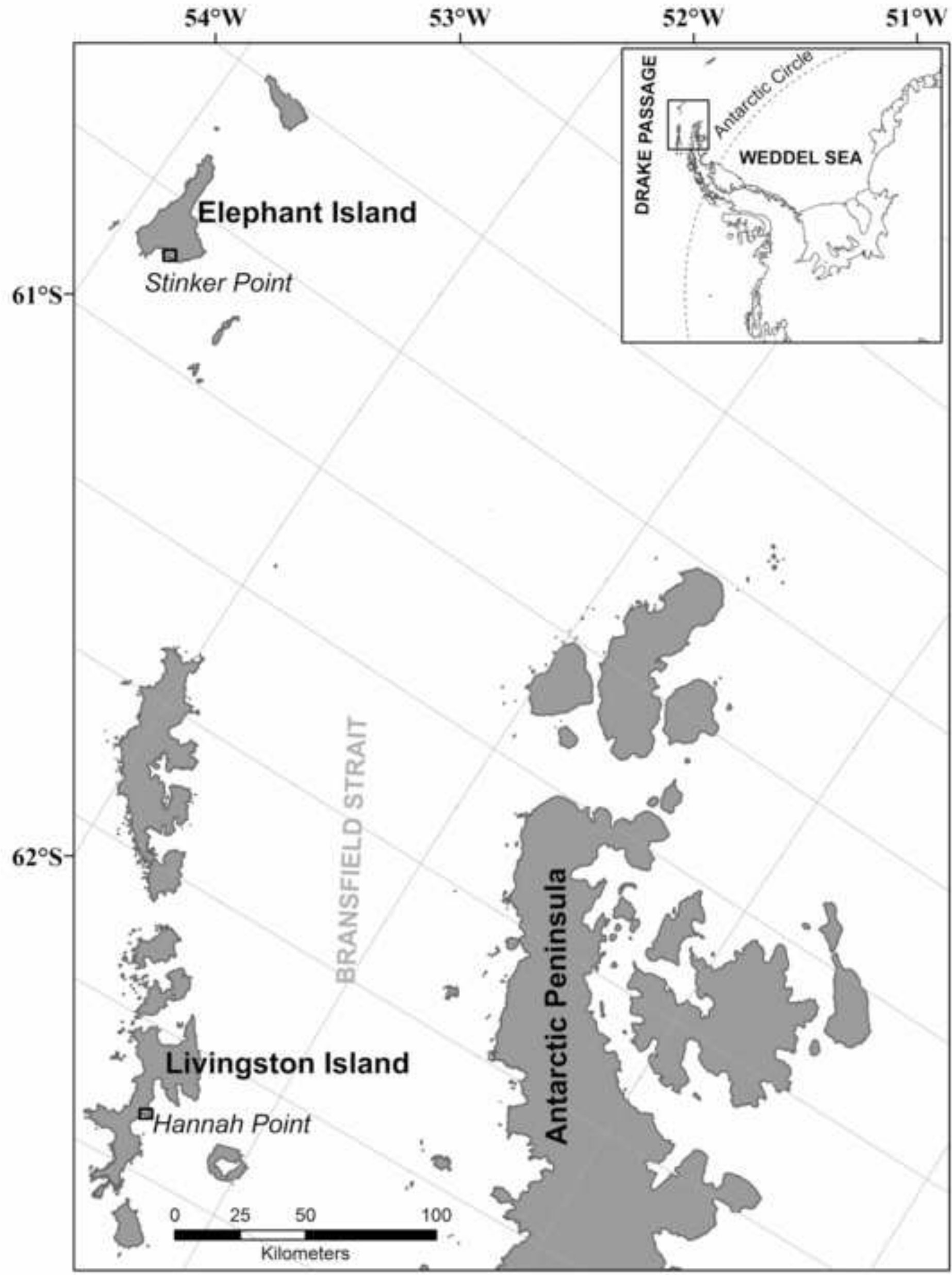




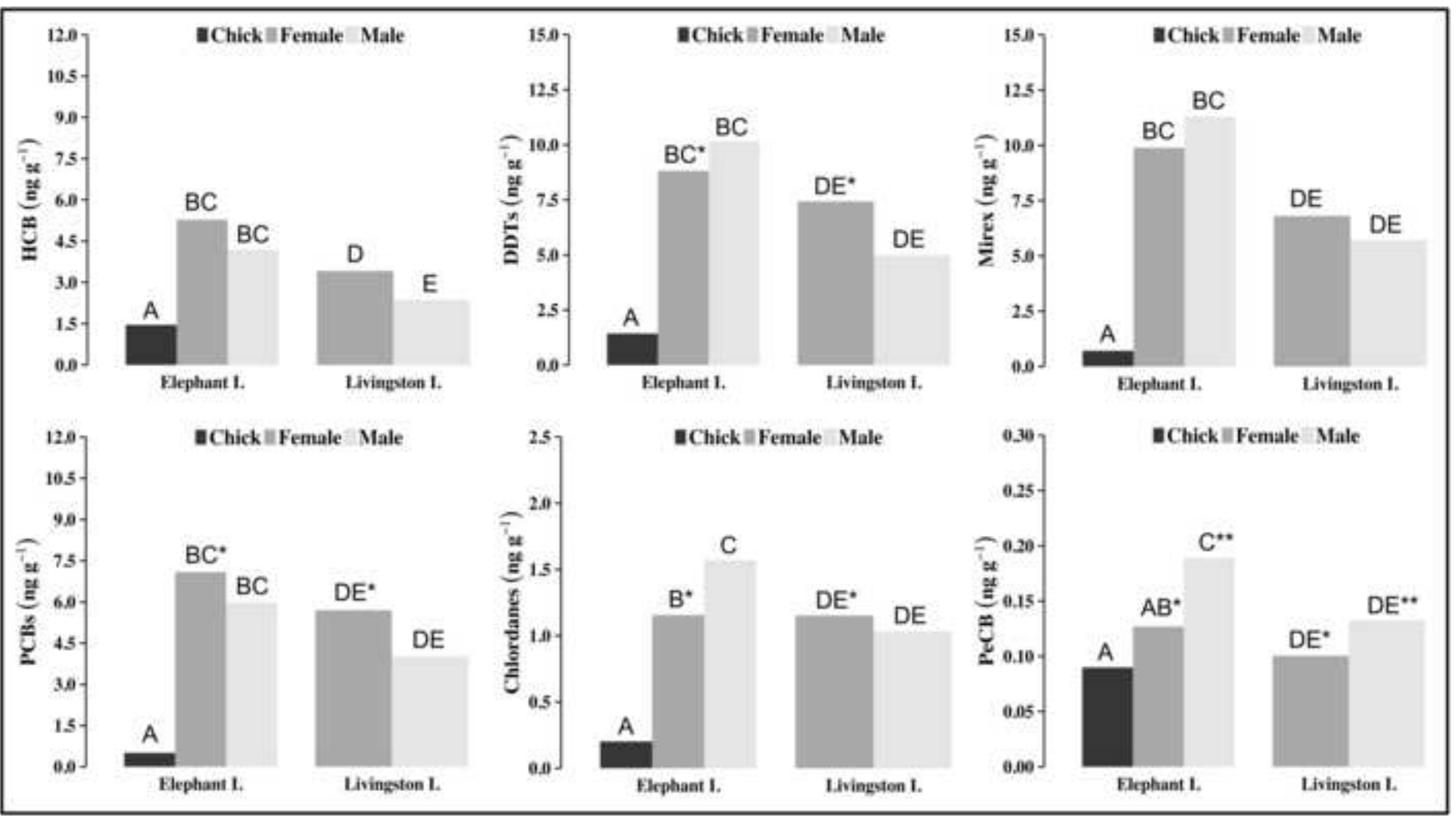




\begin{tabular}{|c|c|c|c|c|c|c|c|c|c|c|c|c|c|c|c|c|c|c|c|c|c|}
\hline \multirow{3}{*}{ Compounds } & \multicolumn{6}{|c|}{ Elephant Island (Nov./2011) } & \multicolumn{9}{|c|}{ Elephant Island (Nov.-Dec./2012; Feb./2013) } & \multicolumn{6}{|c|}{ Livingston Island (Dec./2012) } \\
\hline & \multicolumn{3}{|c|}{ Males $(n=18)$} & \multicolumn{3}{|c|}{ Females $(n=20)$} & \multicolumn{3}{|c|}{ Males $(n=16)$} & \multicolumn{3}{|c|}{ Females $(n=15)$} & \multicolumn{3}{|c|}{ Chicks (n=18) } & \multicolumn{3}{|c|}{ Males $(n=10)$} & \multicolumn{3}{|c|}{ Females $(n=16)$} \\
\hline & Median & Min & Max & Median & Min & Max & Median & Min & Max & Median & Min & Max & Median & Min & Max & Median & Min & Max & Median & Min & Max \\
\hline PCBs & 7.26 & 2.49 & 14.88 & 6.84 & 2.20 & 18.60 & 5.09 & 3.01 & 21.55 & 8.06 & 2.14 & 13.47 & 0.51 & 0.09 & 1.65 & 4.01 & 2.24 & 10.08 & 5.70 & 2.47 & $\mathbf{1 4 . 0}$ \\
\hline di-PCBs & 0.01 & $<0.001$ & 0.01 & 0.01 & $<0.001$ & 0.01 & $<0.001$ & $<0.001$ & $<0.001$ & $<0.001$ & $<0.001$ & $<0.001$ & 0.01 & $<0.001$ & $<0.001$ & 0.01 & $<0.001$ & 0.01 & 0.01 & $<0.001$ & 0.01 \\
\hline tri-PCBs & 0.02 & $<0.001$ & 0.02 & 0.01 & $<0.001$ & 0.01 & 0.01 & $<0.001$ & 0.01 & 0.01 & $<0.001$ & 0.01 & $<0.001$ & $<0.001$ & $<0.001$ & 0.01 & $<0.001$ & 0.03 & 0.02 & $<0.001$ & 0.02 \\
\hline tetra-PCBs & 0.05 & $<0.001$ & 0.16 & 0.05 & 0.02 & 0.17 & 0.04 & $<0.001$ & 0.13 & 0.06 & 0.02 & 0.10 & 0.01 & $<0.001$ & 0.03 & 0.03 & $<0.001$ & 0.06 & 0.02 & $<0.001$ & 0.08 \\
\hline penta-PCBs & 0.80 & 0.35 & 2.46 & 0.97 & 0.34 & 2.34 & 0.60 & 0.35 & 2.35 & 0.96 & 0.34 & 1.47 & 0.06 & 0.01 & 0.31 & 0.48 & 0.33 & 1.06 & 0.76 & 0.32 & 1.84 \\
\hline hexa-PCBs & 3.31 & 1.24 & 7.30 & 3.32 & 1.02 & 9.53 & 2.34 & 1.45 & 10.89 & 3.86 & 1.01 & 6.04 & 0.26 & 0.03 & 0.80 & 1.76 & 1.01 & 5.02 & 2.65 & 1.22 & 7.33 \\
\hline hepta-PCBs & 2.22 & 0.83 & 4.24 & 2.26 & 0.82 & 6.34 & 1.69 & 1.19 & 6.43 & 2.57 & 0.77 & 4.42 & 0.15 & 0.05 & 0.4 & 1.33 & 0.82 & 3.58 & 2.26 & 0.77 & 4.51 \\
\hline octa-PCBs & 0.33 & $<0.01$ & 1.07 & 0.19 & $<0.01$ & 1.51 & 0.48 & $<0.01$ & 1.56 & 0.75 & $<0.01$ & 1.43 & $<0.01$ & $<0.01$ & $<0.01$ & 0.02 & $<0.01$ & 0.36 & 0.25 & $<0.01$ & 0.65 \\
\hline nona-PCBs & 0.12 & $<0.01$ & 0.15 & $<0.01$ & $<0.01$ & $<0.01$ & $<0.01$ & $<0.01$ & $<0.01$ & $<0.01$ & $<0.01$ & $<0.01$ & $<0.01$ & $<0.01$ & $<0.01$ & 0.12 & $<0.01$ & 0.12 & $<0.01$ & $<0.01$ & $<0.01$ \\
\hline PeCB & 0.14 & 0.10 & 0.43 & 0.13 & 0.06 & 0.26 & 0.22 & 0.13 & 0.33 & 0.10 & 0.08 & 0.29 & 0.09 & 0.06 & 0.17 & 0.13 & 0.09 & 0.28 & 0.10 & 0.08 & 0.23 \\
\hline HCB & 4.44 & 2.28 & 12.1 & 5.09 & 2.22 & 9.13 & 4.19 & 2.29 & 10.3 & 5.45 & 2.42 & 7.79 & 1.46 & 0.98 & 3.61 & 2.36 & 1.85 & 4.17 & 3.42 & 1.86 & 6.65 \\
\hline $\mathbf{D D}^{\prime}$ & & 4 & 3 & 1 & 2 & 27 & & & & & 2. & & 1. & 0.6 & 5 & & 3. & 16 & 7.43 & 2.16 & 22.9 \\
\hline 4,4'-DDE & 13.7 & 3.86 & 33.8 & 1 & 2.3 & 26 & 7.19 & 4.8 & 30 & 6.62 & 2.48 & 14.0 & 1.38 & 0.55 & 4. & 4.68 & 3.74 & 16.0 & 6.78 & 1.93 & 21.3 \\
\hline $2,4^{\prime}-\mathrm{D}$ & $<0.004$ & $<0.004$ & $<0.004$ & 0.01 & $<0.004$ & 0.0 & $<0.004$ & $<0.004$ & $<0.004$ & $<0.004$ & $<0.004$ & $<0.004$ & $<0.004$ & $<0.004$ & $<0.004$ & $<0.004$ & $<0.004$ & $<0.004$ & $<0.004$ & $<0.004$ & $<0.004$ \\
\hline 4,4'-1 & 44 & $<0.01$ & 0.39 & 0 & $<0.01$ & 0. & & $<0.01$ & 0.46 & 0 & $<0.01$ & 0.33 & 0.03 & $<0.01$ & 0. & 0.04 & $<0.01$ & 0.04 & 0.08 & $<0.01$ & 0.33 \\
\hline 4,4'-DDT & 0.55 & 0.17 & 2.66 & 0.60 & 0.18 & 1.86 & 0.36 & 0.14 & 3.09 & 0.62 & 0.11 & 2.61 & 0.11 & $<0.01$ & 0.29 & 0.35 & 0.17 & 0.81 & 0.54 & 0.19 & 3.98 \\
\hline Mirex & 13.8 & 6.62 & 29.2 & 10.0 & 2.56 & 43.1 & 9.07 & 5.21 & 35.7 & 8.72 & 2.55 & 16.1 & 0.71 & 0.28 & 2.63 & 5.72 & 3.57 & 12.4 & 6.81 & 3.16 & 36.2 \\
\hline & & 0 & & & & 2.6 & & & & & 0. & 1. & 0.20 & 0 . & 0 . & 1.03 & 0.65 & 1.98 & 1.15 & 0.46 & 2.27 \\
\hline Oxyc & 1.60 & 0.76 & 3.73 & 1.14 & 0.41 & 2.6 & 1.2 & 0.9 & 3.1 & 1. & 0.55 & 1.71 & 0.19 & 0.10 & 0.73 & 0.98 & 0.60 & 1.92 & 1.10 & 0.43 & 2.17 \\
\hline trans -nonachlor & 0.03 & $<0.01$ & 0.07 & 0.03 & $<0.01$ & 0.08 & 0.04 & 0.03 & 0.15 & 0.06 & $<0.01$ & 0.13 & 0.02 & $<0.01$ & 0.17 & 0.05 & 0.02 & 0.10 & 0.05 & 0.02 & 0.17 \\
\hline Lipids (mg g $\left.{ }^{-1}\right)$ & 3.47 & 2.40 & 3.97 & 3.48 & 2.10 & 4.53 & 3.53 & 2.03 & 4.80 & 3.53 & 2.53 & 4.87 & 3.52 & 2.80 & 6.53 & 3.83 & 2.87 & 5.30 & 3.58 & 2.77 & 5.33 \\
\hline
\end{tabular}




\begin{tabular}{|c|c|c|c|c|c|c|c|c|c|c|}
\hline Species & Local & Year & PCBs & DDTs & Mirex & Chlordanes & HCHs & HCB & PBDES & Reference \\
\hline $\begin{array}{l}\text { Southern Giant Petrel } \\
\text { (Macronectes giganteus) }\end{array}$ & $\begin{array}{l}\text { South Shetland Islands } \\
\text { (Antarctica) }\end{array}$ & $2011 / 2012$ & $\begin{array}{c}5.96 \\
(2.14-21.5)\end{array}$ & $\begin{array}{c}8.42 \\
(2.16-34.52)\end{array}$ & $\begin{array}{c}8.84 \\
(2.55-43.1)\end{array}$ & $\begin{array}{c}1.26 \\
(0.44-3.77)\end{array}$ & $<0.01$ & $\begin{array}{c}4.19 \\
(1.85-12.1)\end{array}$ & $<0.003$ & This study \\
\hline $\begin{array}{l}\text { Wandering Albatross } \\
\text { (Diomedea exulans) }\end{array}$ & $\begin{array}{l}\text { Crozet Archipelago } \\
\text { (Subantarctic region) }\end{array}$ & 2008 & $\begin{array}{c}5.70 \\
(0.10-676)\end{array}$ & $\begin{array}{c}5.40 \\
(<0.05-28.9)\end{array}$ & $\begin{array}{c}20.7 \\
(<0.05-6.20)\end{array}$ & $\begin{array}{c}1.40 \\
(<0.04-5.20)\end{array}$ & $\begin{array}{c}1.10 \\
(<0.04-3.60)\end{array}$ & $\begin{array}{c}1.80 \\
(<0.03-10.0)\end{array}$ & $\begin{array}{c}0.60 \\
(<0.03-1.90)\end{array}$ & $\begin{array}{l}\text { Carravieri et al. } \\
\text { (2014) }\end{array}$ \\
\hline $\begin{array}{l}\text { South Polar Skua } \\
\text { (Catharacta maccormicki) }\end{array}$ & $\begin{array}{l}\text { Svarthamaren } \\
\text { (Antarctica) }\end{array}$ & $2001 / 2002$ & $\begin{array}{c}9.00 \\
(1.00-50.5)\end{array}$ & $\begin{array}{c}6.80^{(2)} \\
(0.40-40.9)\end{array}$ & $\begin{array}{c}20.7 \\
(1.00-69.2)\end{array}$ & $\begin{array}{c}2.30 \\
(<0.10-4.39)\end{array}$ & $\begin{array}{c}0.10 \\
(0.60-8.70)\end{array}$ & $\begin{array}{c}7.20 \\
(0.60-21.2)\end{array}$ & - & $\begin{array}{l}\text { Bustnes et al. } \\
\quad(2006)\end{array}$ \\
\hline $\begin{array}{l}\text { Great Skua } \\
\text { (Catharacta skua) }\end{array}$ & Bjørnøya (North Atlantic) & 2009 & $\begin{array}{c}1720 \\
(373-6181)\end{array}$ & $\begin{array}{c}516 \\
(59.0-1305)\end{array}$ & $\begin{array}{c}48.0 \\
(7.00-134)\end{array}$ & $\begin{array}{c}123 \\
(25.0-378)\end{array}$ & $\begin{array}{c}1.80 \\
(0.50-11.0)\end{array}$ & $\begin{array}{c}24.0 \\
(5.00-57.0)\end{array}$ & $\begin{array}{c}17.0 \\
(1.00-210)\end{array}$ & $\begin{array}{l}\text { Sonne et al. } \\
\quad(2013)\end{array}$ \\
\hline $\begin{array}{l}\text { Great Skua } \\
\text { (Catharacta skua) }\end{array}$ & Iceland (North Atlantic) & 2009 & $\begin{array}{c}323 \\
(94.0-1889)\end{array}$ & $\begin{array}{c}115 \\
(20.0-792)\end{array}$ & $\begin{array}{c}9.00 \\
(2.00-64)\end{array}$ & $\begin{array}{c}31.0 \\
(6.00-120)\end{array}$ & $\begin{array}{c}0.70 \\
(0.02-4.00)\end{array}$ & $\begin{array}{c}4.00 \\
(0.70-11.0)\end{array}$ & $\begin{array}{c}10.0 \\
(1.00-51.0)\end{array}$ & $\begin{array}{l}\text { Sonne et al. } \\
\text { (2013) }\end{array}$ \\
\hline $\begin{array}{l}\text { Great Skua } \\
\text { (Catharacta skua) }\end{array}$ & Shetland (North Atlantic) & 2009 & $\begin{array}{c}183 \\
(65.0-965)\end{array}$ & $\begin{array}{c}37.0 \\
(9.00-355)\end{array}$ & $\begin{array}{c}2.00 \\
(0.80-26.0)\end{array}$ & $\begin{array}{c}14.0 \\
(5.00-60.0)\end{array}$ & $\begin{array}{c}0.17 \\
(0.06-1.20)\end{array}$ & $\begin{array}{c}2.00 \\
(0.70-13.0)\end{array}$ & $\begin{array}{c}6.00 \\
(3.00-15.0)\end{array}$ & $\begin{array}{l}\text { Sonne et al. } \\
\text { (2013) }\end{array}$ \\
\hline $\begin{array}{l}\text { Glaucous Gull } \\
\text { (Larus hyperboreus) }\end{array}$ & $\begin{array}{c}\text { Bear Island } \\
\text { (Norwegian Arctic) }\end{array}$ & 2001 & $\begin{array}{c}51.4 \\
(84.3-1576)\end{array}$ & $\begin{array}{c}8.40^{(2)} \\
(18.5-246)\end{array}$ & $\begin{array}{c}6.90 \\
(1.60-28.4)\end{array}$ & $\begin{array}{c}14.3 \\
(0.40-50.1)\end{array}$ & $\begin{array}{c}1.20 \\
(0.20-5.20)\end{array}$ & $\begin{array}{c}20.7 \\
(6.80-45.7)\end{array}$ & - & $\begin{array}{l}\text { Bustnes et al. } \\
\quad(2006)\end{array}$ \\
\hline
\end{tabular}

${ }^{1}$ Median concentrations in the first row (except for Bustnes et al. 2006, which shows mean concentrations) and ranges in the second row.

${ }^{2} 4,4-\mathrm{DDE}$ 


\begin{tabular}{|c|c|c|c|c|c|c|c|c|c|c|}
\hline \multirow{3}{*}{$\begin{array}{c}\text { Ring number } \\
\text { Compounds }\end{array}$} & \multirow{2}{*}{\multicolumn{2}{|c|}{$\begin{array}{c}\text { Male } \\
\text { V27716 }\end{array}$}} & \multicolumn{8}{|c|}{ Female } \\
\hline & & & \multicolumn{2}{|c|}{ V28122 } & \multicolumn{2}{|c|}{ V27966 } & \multicolumn{2}{|c|}{ V27737 } & \multicolumn{2}{|c|}{ V27743 } \\
\hline & 2011 & 2012 & 2011 & 2012 & 2011 & 2012 & 2011 & 2012 & 2011 & 2012 \\
\hline PCBs & 14.9 & 16.9 & 3.47 & 5.41 & 2.20 & 2.14 & 10.6 & 11.0 & 6.59 & 8.06 \\
\hline Pentachlorobenzene & 0.18 & 0.23 & 0.13 & 0.10 & 0.08 & 0.09 & 0.12 & 0.09 & 0.13 & 0.15 \\
\hline НСВ & 6.20 & 6.71 & 4.04 & 4.27 & 2.22 & 2.58 & 5.47 & 5.22 & 4.89 & 5.45 \\
\hline DDTs & 33.9 & 33.2 & 7.00 & 7.29 & 2.75 & 2.90 & 10.6 & 7.06 & 8.82 & 9.70 \\
\hline Mirex & 12.2 & 19.4 & 4.42 & 7.84 & 3.39 & 2.55 & 8.54 & 7.94 & 9.90 & 7.26 \\
\hline Chlordanes & 2.85 & 2.42 & 0.94 & 1.08 & 0.44 & 0.58 & 1.16 & 1.15 & 1.13 & 1.19 \\
\hline
\end{tabular}

